\title{
INTEGRATION OF PEDAGOGIC TECHNOLOGIES AND CREATIVE TOOLS FOR ACHIEVING BALANCED COMPETENCE OF A POTENTIAL SPECIALIST
}

Gulnara Akhmedyanova, Orenburg State University, ahmedyanova@bk.ru

\begin{abstract}
A graduated bachelor must possess not only knowledge, but also the certain professional-personal qualities, that are balanced in respect of these two aspects of competence. As these aspects are achieved by the different instruments, teaching technologies and creative techniques, raises the question of their coordination. It is achieved due to the development of the plan of teaching on the basis of the creativemodular technology, and then the realization of this plan with separate revision and correction of learning outcomes in relation to these aspects of competence. The result of developed hierarchical two-aspect model achievement of competence allows efficiently in the process of learning resolving imbalances in the integration of educational technologies and creative tools.
\end{abstract}

UDC Number: 378.147:005, DOI: 10.12955/cbup.2013.35

Keywords: competence, pedagogic technologies, creative tools

\section{Introduction}

In modern teaching process pedagogic technologies and creative tools are considered as independent means of teaching. But pedagogic technologies convey knowledge within a discipline quite well and develop mainly cognitive-operational component of the competence while creative tools develop professional-personal one. The inconsistency of the above mentioned teaching means will result either in an erudite but lacking initiative specialist or in a highly initiative but lacking knowledge one. It's clear that a graduate competence should be balanced in respect to both these components, and the only way to achieve this is the integration of pedagogic technologies and applied creative tools.

Primarily we consider competence (Zimnyaya, 2006) as the ability to connect knowledge and situation or, in a wider sense, as the ability to find out, discover the procedure (of knowledge, operation) suitable for resolving a problem. This notion is much wider than the notions of knowledge, abilities, and skills as it involves individual's orientation, overcoming stereotypes, understanding problems, flexible thinking. Unlike skills it is conscious; unlike abilities it is transferrable and improvable, unlike knowledge it is operational (really or mentally).

\section{Literature review}

It follows that the notion of competence comprises two aspects: cognitive-operational and professional-personal. It is essential because these aspects are developed by means of different pedagogic tools, pedagogic techniques and creative methods as well as the assessment of achieved 
levels in these aspects is different. So, it follows naturally to supplement the definition of competence with the notion of harmonic balance of cognitive-operational and professional-personal components and to name it as balanced competence (Akhmedyanova, 2011).

Any activity, as Bespalko (1989) puts it, can be either a technology or an art. Art is based on intuition, technology is based on science. "It starts with art and results in technology in order to start it all again" (Slastenin, 2002). In studying activity we can also distinguish between creativity (Ponomarev, 1996) and technology (Selevko, 2005) aspects. All the achievements in the studying process are dependent on the awareness of their proportions and on their comprehensive use. It's obvious that the extent of integration of these components is essential for improving the teaching quality, for better balance of cognitive-operational and professional-personal components, for better realization of all the subjects of educational process (Andreev, 2006).

On this assumption, we may analyze technological and creative pedagogic tools in terms of dialectics of unity and struggle of opposites. Their common point is that they both contribute to getting the result. However in one case, technological, the result is achieved in mass and guaranteed by meeting certain requirements, in the other case, creative, the result is produced by inspiration, it is spontaneous and often unique.

Therefore, technological and creative components of educational process can't be separated, they should be considered as the two mutually complementing tools. The problem is just to determine the proportions of these two components, necessary to form the optimal (balanced) competence of a potential specialist.

The perspective of mutual complementing of these tools while forming the competence does not appear automatically, that is why we need to investigate the moment and the measure of their influence.

Processing methods of teaching affect not only the process of learning, but also develop, to some extent, personal qualities of students, as well as creative ways develop not only personal qualities, but affect the absorption of knowledge. Ignoring this interference, we regard these two effects independent in the first approximation. Thus it becomes possible to evaluate separately the result of the educational process in relation to cognitive- operational and professional-personal aspects, on the basis of corresponding monitoring, and according to this evaluation to correct the impact measure of any of these tools.

Scores obtained in the course of the monitoring program should be compared with the requirements for the competence level at every stage of the educational process. In their turn, these requirements are developed at a higher level, in the course of the strategy development of the competence formation (Ahmedyanova \& Pishchukhin, 2010).

If a deviation of one of the two aspects of competence occurs, as a result of the monitoring, it is possible to change the impact on the educational process, either by means of changing the educational technology, or by the applicable level of creativity.

The process of management competencies formation described above may be regarded as hierarchical and two-aspect. Naturally, the greater the deviations are, the longer should be the application of the corresponding tool. The intensity of the educational technology impact can be adjusted by changing the type of technology, and of the creative tools by means of level changing. 
Learning technologies, depending on their types, may have different effects of the didactic impact and therefore different contributions to the final competence. They should be classified by this criterion. A simplified classification (Ksenzova, 2005) seems in this respect to be the most suitable. In accordance with this classification they distinguish: the explanatory-illustrative teaching technologies; the personality-oriented training technologies, the developing training technology.

The type of the applied technology (Tretyakov, 2003; Borytko, 2007) is strongly dependent not only on the level of students, but also on the content of transmitted knowledge. If the knowledge is not very complicated, it can easily be transferred on the basis of the explanatory-illustrative technology. More complicated knowledge may require the personality-oriented approach. Finally, the complicated knowledge, combined with the students` unwillingness may require the necessary developing training. In this case, the higher level of technology includes the previous lower ones.

Creativity, according to the level given in the educational process, can also have a different effect of didactic impact. There are four generally accepted levels of creative activity: reproduction, modernization, production and innovation. These levels have the increasing degree of impact on developing aspects of professional-personal qualities.

Therefore, the organization of the educational process can be based on educational feedback on two aspects of competence: cognitive-operational and professional-personal.

Summing up the above analysis, it can be stated that the transfer of the knowledge to the student and the development of professional-personal qualities should be made by various pedagogical tools respectively: by teaching technologies and creative tools. In this case the deviations are possible in either direction, which will be revealed on the interim evaluation. In this case, the recommendations after assessing may contain the proposals to strengthen creative or technological impact, to increase their duration, to deepen the substantive aspect (changing the level, the depth of content).

\section{Data and Methodology}

Thus, the technique, matching the intensity of the technological and creative teacher training tools to maximize the balance between "knowledge" and the personal aspects of the future specialist competence, might look like this: a course of discipline taught should be divided into modules, the number and the content of which should contribute to the implementation of effective control of each module distortions made in the previous training modules. In addition, each module must prescribe measures of "knowledge" and the creative components of competence acquired during the study of the module; in the course of modular training it is necessary "to interweave" flexibly into applied pedagogical technology creative receptions of the various problems' solution of a professional orientation, correcting the depth of influence of these pedagogical tools with results previous in front of each module of competence estimation; at the end of each module it is necessary to carry out a separate estimation of knowledge and professional and personal competence aspects. If the estimation of the first aspect is developed enough in a four-point scale (excellent, good, satisfactory and unsatisfactory), then for the estimation of the second aspect, in order to avoid the ambiguity of result, sets of modular tests (or creative tasks) have to be developed; for getting the feedback it is necessary to compare results of the estimation stage separately in accordance with knowledge aspect, for example, in a section of a GPA and according to the professional-personal qualities' aspect in a section of the average percent of correctly chosen test answers, or correctly carried out creative tasks, with a measure put in the corresponding module at the first stage of this technique performance. In case of 
imbalance of the results with the plan it is necessary to develop correcting actions of technological, creative character, or another in sizes proportional to the allowed mismatch.

At the first step of the described technique the maximum qualification and creative activity is required from the teacher: at defining the quantities and the maintenance of modules into which the discipline breaks, and at making test (creative) tasks and, the most important, at a task of knowledge measures and creative competence component. These components of the first step are so important that together they form each discipline teaching strategy.

The second step is the most practical - here is the developed strategy realized, the foundations for the future competence are laid. Not all mistakes, made at this stage, can be corrected, also as well as not all missed opportunities can be compensated. All this emphasizes the fundamental importance of the described step.

The importance of estimation in any technique is obvious. Nevertheless, in this technique the estimation is specific as it is important not only its absolute aspect concerning knowledge and professional and personal competence components, but also relative aspect - the ratios of these components with each other.

Without the feedback declared at the fourth step of this technique, correcting the correction of training process becomes impossible. The sign of correction defined at this step is important also. Positive aspects of the previous training have to remain and be increased, for elimination of the negative ones it is necessary to reveal and eliminate the reasons of their emergence.

Thus, the developed coordinating technique allows, on the basis of stage-by-stage and modular correction and feedback introduction in the course of training on each discipline, achieving the maximum balance of cognitive and operational and professional and personal competence components of the graduate of higher education institution.

Coming back to the first step of this technique, being hierarchically the highest, we note according to researches (Yurkovets, 2008) that it is the most convenient to apply modular training (Yuzyavichene, 1990) to its performance. Thus "the module has to represent itself rather independent unit of the educational program of vocational training disciplines, directed on the formation of the certain structure of professional competences. Obligatory maintenance is diagnosing not only the end result at the end, but also stages of passing of the program trainees. Thereby, there is an objective level assessment of formation of this or that competence". The essence of modular and competence-based approach to training process is expressed in it.

The structure and a sequence of modules with the best coordination with each other become here important. The developed in advance sequence of the coordinated and adaptive to changing conditions modules can be called as the strategy of discipline teaching.

Creation of such strategy is subordinated to several principles. At first, on the basis of the uniform loading principle, the discipline content is carried on semester, thus breaking it into thematic modules. Then we bring in strategy a creative component, using the principle of initial competence (according to this principle to some extent initial creativity all have being trained) and the principle of compliance to the education standard (by this principle final creativity of the being trained students has to correspond to the level set by the standard). 
Distributing the development of creativity in the modules we stick to the principle of a smooth increase of creative work volumes and the principle of following the creative tasks topics in the subsequent module to the content of the preceding module.

In our opinion, a more detailed formation of the teaching discipline strategy is easier to conduct on the basis of the metasystem principle (Mironov \& Pishchukhin, 2003). J.Klir distinguishes two ways of integrating systems into a single unit (Klir, 1985): the creation of a structured system and the creation of a metasystem. In contrast to the structured system, a metasystem includes independent or loosely connected system, of which it chooses the one that is most adequate for the operation in the current situation. If you change the environment the functioning system is also changed. While the structured system responds to changes in the environment only with the change of signals in interrelations, metasystem also reacts both with the change of signals within the selected system and the change of the system itself, if it is necessary, that is, the changes within metasystem are stronger.

Based on the differences of the metasystem from the structured one, we can formulate six objectives of metasystem approach which do not occur in the normal system approach. As the metasystem occurs when and where and the range of the problem being addressed is so wide that it is not covered by the operation of a system, or it does not work effectively in some parts of the range (due to this we have to recruit for different parts of their range), you need to find the boundary between the subbands of the effective functioning of a system.

The systems must be prepared for the operation by the time of their use, and therefore it is necessary to develop a pre-sequence of switching time, that is, to develop a strategy of switching. Finally, the compatibility of systems should be considered, control resources should be optimally allocated among them and the most effective system should be always selected into the metasystem.

If we return to the module-competence approach and look at the collection of modules as a metasystem, and this is possible only when the modules allow an arbitrary sequence of their study, the most important task is developing the teaching strategy of the subject, by which we may understand the optimal sequence of modules in the sense of education quality.

The planning strategy process is based on the strategy of the choice matrix (Yurkovets, 2008) in one direction reflecting the hierarchy, and in the other - metasystematics. Synthesis begins with the targeting of the educational process. The target can vary considerably, but generally, the target of each discipline teaching is the transfer of knowledge, training creative professionals, improving the quality of education in general. In modular training the target will be achieved in solving problems related to the implementation of modules constituting the content of the discipline. In their turn, these problems can be solved in different ways: by direct (face to face), by indirect (remote), by combined, or the module can be implemented independently by a student.

\section{Data and results}

Before the experiment students` interviewing was held. It presented a significant disbalance of the educational process towards technology. Pedagogical efforts were directed to strengthen the creative content of the teaching process.

The experiment involved examined group (22 people) of the $3 \mathrm{~d}$ course System Analysis and Management (Bachelor students) and control group (14 people) of the 4th course System Analysis 
and Management (Bachelor students). The experiment's aim was to ascertain the degree of students creativity growth, interest to the chosen profession and the discipline. The results are summarized in Table 1.

Table 1: Change of students creativity

\begin{tabular}{|l|c|c|}
\hline Type of group & $\begin{array}{c}\text { Activity(the average number of questions } \\
\text { during a lecture) }\end{array}$ & Number of classes missed \\
\hline Examined & 12 & 2 \\
\hline Control & 2 & 6 \\
\hline
\end{tabular}

Source: Author

\section{Discussion}

As the criteria for estimation the activity level of group we have taken the average number of the questions asked by students at each lection during the term and the amount of classes missed by students. According to Table 1 the number of questions highly increased while the number of classes missed considerably reduced. Thus we came to a conclusion that the audience's initiative and creative orientation have grown distinctly, improving the mentioned situation.

\section{Conclusion}

Thus, the proposed method improves the quality of education due to the development of teaching plan on the basis of the creative-module technology. Separate evaluation and correction of educational results related to cognitive-operational and professional-personal competence aspects have been fulfiled in this program. As a result hierarchical two-aspects model competence formation was developed. Balanced integration of pedagogical technologies and creative techniques allows achieving the necessary competence, on the basis of stage-by-stage coordination of modules in disciplines, and at interdisciplinary levels that leads to a bachelor graduate competence improvement.

\section{References}

Andreev, V. I. (2006). Pedagogika: uchebnyi kurs dlya samorazvitiya [Pedagogics: a training course for self-development]. Kazan, Russia: Centr Innovacionnyh tehnologiy .

Ahmedyanova, G. F. (2011). Ingenernaya kompetentnost kak rezultat integracii tvorcheskogo i technologicheskogo komponentov obucheniya [Engineering competence as a result of the creative and technological training components integration]. Fundamentalnye Issledovaniya [Fundamental Research], 8 (1), 13-16.

Ahmedyanova, G. F. \& Pishchukhin, A. M. (2007). O strategii modulnogo prepodavaniya discipliny v vuze [The strategy of modular teaching the subject at high schools]. Uspehi sovremennogo estestvoznaniya [Successes of modern sciences], 10, 51-52.

Bespalko, V. P. (1989). Slagaemye pedagogicheskoi tehnologii [Composed pedagogical technology]. Moscow, Russia: Pedagogica. 
Borytko, N. M. (ed.). (2007). Pedagogika [Pedagogics]. Moscow, Russia: Izdatelskii ctntr Akademiya.

Klir, J. (1985). Architecture of systems problem solving . New York, NY: Plenum Press. http://dx.doi.org/10.1007/978-1-4757-1168-4

Ksenzova, G. Y. (2005). Innovacionnye tehnologii obucheniya I vospitaniya shkolnikov: Uchebnoe posobie [Innovative technology of schoolchildren training and education. Teaching Book]. Moscow, Russia : Pedagogicheskoe obshchestvo Rossii.

Mironov, S. V. \& Pishchukhin, A. M. (2005). Metasistemnyi podhod k upravleniyu [Metasystem approach in management]. Orenburg, Russia: IPK.

Ponomarev, Y. A. (1996). Psihologiya tvorchestva i pedagogika [The psychology of creativity and pedagogics]. Moscow, Russia: Obrazovanie. PMCid:PMC2143431

Selevko, G. K. (2005). Pedagogicheskie tehnologii na osnove pedagogicheskih i metodicheskih usovershenstvovaniy [Pedagogical technologies on the basis of didactic and methodical improvements.] Moscow, Russia: Vysshaya shkola.

Slastenin, V. A. (ed.) (2002). Pedagogica: Uchebnik [Pedagogics: Teaching Book]. Moscow, Russia: Izdatelskiy Centr Akademiya.

Tretyakov, P. I. (ed.) (2003). Adaptivnoe upravlenie pedagogicheskimi sistemami [Adaptive management of pedagogical systems]. Moscow, Russia: Izdatelskiy centr Akademiya.

Yurkovets, O. P. (2008). Formirovanie professionalnyh kompetenciy tehnikov-programmistov na osnove tehnologii modulno-kompetentnostnogo obucheniya [The professional competencies formation of technician-programmists based on modular competency training technology.] Tolyatti, Russia: Avtoreferat diss. na soiskanie uch. stepeni kand. ped. nauk .

Yuzyavichene, P. A. (1990). Teoriya i praktika modulnogo obucheniya [Theory and practice of modular training.] Sov. pedagogika, No 1, 55-60.

Zimnyaya, I. A. (2006). Kompetentnostnyi podhod. Kakovo ego mesto v sisteme sovremennyh podhodov k problemam obrazovaniya? [The competence-based approach. What is its place in the system of modern approaches to the problems of education?]. Vysshee obrazovanie segodnya [Higher education today], No. 8, 56-59. 